\title{
A Case of Gastric Granular Cell Tumor: Review of Literature and Features of Endoscopic Ultrasonography
}

\author{
Dong Jun Kim, Hyung Wook Kim, Su Bum Park, Cheol Woong Choi, Dae Hwan Kang, Joung Boom Hong, Byoung Hoon Ji ${ }^{1}$ \\ Chang Seok Lee ${ }^{2}$ \\ Department of Internal Medicine, Medical Research Institute, Pusan National University School of Medicine and Research Institute for \\ Convergence of Biomedical Science and Technology, Pusan National University Yangsan Hospital, Yangsan, Department of Internal Medicine, \\ Dong-Eui Medical Center ${ }^{1}$, Department of Internal Medicine, Bongseng Memorial Hospital ${ }^{2}$, Busan, Korea
}

\begin{abstract}
Granular cell tumor was originally described as granular cell myoblastoma by Abrikossoff. The incidence of GCT in the gastrointestinal tract is low, and most granular cell tumors occur in the esophagus and large bowel. Gastric granular cell tumors are rare and difficult to distinguish from carcinoid tumors by gross endoscopic findings and endoscopic ultrasonography findings. We report a case of gastric granular cell tumor, treated by endoscopic submucosal dissection, and review the endoscopic ultrasonography findings of recently reported gastric granular cell tumors. (Korean J Helicobacter Up Gastrointest Res 2015;15:59-63)
\end{abstract}

Key Words: Granular cell tumor; Endosonography; Stomach

\section{INTRODUCTION}

Granular cell tumor (GCT) was described as granular cell myoblastoma by Abrikossoff for the first time in 1926. GCTs are uncommon, usually benign neoplasm that can be located at any sites. The incidence of GCT in the gastrointestinal (GI) tract is low. Most of GI GCTs are in the esophagus and large bowel, but rarely in the stomach. ${ }^{1,2}$ At least 50\% of gastric GCTs are associated with synchronous esophageal GCTs and they usually occur in the proximal stomach. ${ }^{3}$ GCTs arising in the stomach are almost benign, and only a case of malignant gastric GCT was reported. ${ }^{4}$ Histologically, GCTs consist of large polygonal and fusiform cells disposed in compact nests. GCTs are almost positive for $\mathrm{S}-100$ protein and neuron specific enolase (NSE), suggesting that GCTs are derived from Schwann cells. ${ }^{5}$ On the endoscopy, most GCTs appear as sessile, small, yellowish-white in color, and covered by normal appearing mucosa. ${ }^{6}$ Conventional endoscopic findings and EUS findings of carcinoid tumors are similar to

Received: November 6, 2014 Accepted: February 9, 2015

Corresponding author: Hyung Wook Kim

Department of Internal Medicine, Medical Research Institute, Pusan National University School of Medicine and Research Institute for Convergence of Biomedical Science and Technology, Pusan National University Yangsan Hospital, 20, Geumo-ro, Mulgeum-eup, Yangsan 626-770, Korea

Tel: +82-55-360-1534, Fax: +82-55-360-1536, E-mail: mdkhwook@gmail.com
GCTs, therefore differential diagnosis between GCTs and carcinoid tumors is very difficult. ${ }^{7}$ Patti et al. ${ }^{8}$ reported a case of gastric GCT in 2006, and reviewed 5 cases of gastric GCTs. Since 2006, eleven cases of gastric GCT have been reported. ${ }^{9-15}$ Ten cases could be found in the PubMed (US National Library of Medicine) and were written in English, ${ }^{9,12-15}$ and a single case was written in Korean. ${ }^{11}$ Among of eleven cases, EUS was performed in six cases. ${ }^{11,12,15}$ We report a case of a 31-year-old man with GCT of stomach, seemed like carcinoid, and we review the endoscopic findings and EUS findings of recent gastric GCT cases.

\section{CASE REPORT}

A 31-year-old man was admitted to our hospital for further evaluation of a gastric subepithelial lesion. He underwent upper GI endoscopy for a health check-up at local medical center. Endoscopic examination of local medical center revealed a $6 \mathrm{~mm}$ sized subepithelial lesion in the cardia of stomach. An endoscopic biopsy was performed, and histopathological examination of endoscopic biopsy showed a partially some large polygonal cells with eosinophilic granular cytoplasm in lamina propria. It suggested a GCT, and then he was referred to Pusan

Copyright $\odot 2015$ Korean College of Helicobacter and Upper Gastrointestinal Research

(ङ) The Korean Journal of Helicobacter and Upper Gastrointestinal Research is an Open-Access Journal. All articles are distributed under the terms of the Creative Commons Attribution Non-Commercial License (http://creativecommons.org/licenses/by-nc/3.0) which permits unrestricted non-commercial use, distribution, and reproduction in any medium, provided the original work is properly cited. 
National University Yangsan Hospital. He had no significant medical history. At the time of admission, AST was $50 \mathrm{IU} / \mathrm{L}$, and ALT was $99 \mathrm{IU} / \mathrm{L}$. Other laboratory studies, including complete blood count, coagulation studies, electrolytes, and creatinine, were within normal limit. His height and weight was $171.9 \mathrm{~cm}$ and $91.4 \mathrm{~kg}$, and his body mass index was $30.93 \mathrm{~kg} / \mathrm{m}^{2}$. He had no cause of liver enzyme elevation except obesity. A CT of

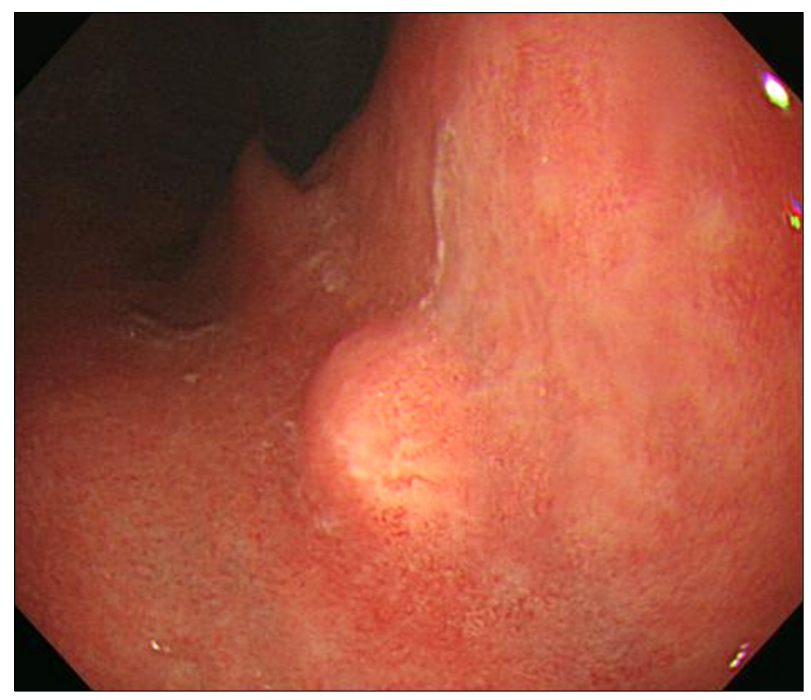

Fig. 1. Endoscopy revealed a yellow-whitish, hard and mobile subepithelial lesion in the cardia of the stomach. The tumor was difficult to distinguish from carcinoid tumor.

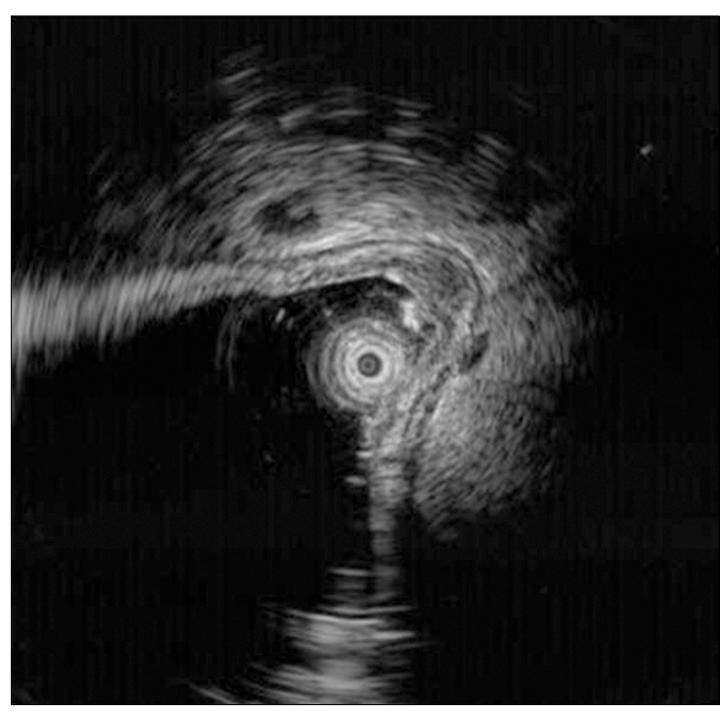

Fig. 2. EUS revealed a smooth, well demarcated, homogeneous hypoechoic solid lesion in 2nd and 3rd layer. abdomen showed slightly high density of liver, it was considered fatty liver.

Upper GI endoscopy revealed a less than $10 \mathrm{~mm}$ sized, yellow-whitish, hard subepithelial lesion in the cardia of the stomach (Fig. 1). There was no specific lesion in the esophagus. EUS was subsequently performed for tumor invasion depth (Fig. 2). EUS showed a $6 \times 4 \mathrm{~mm}$ sized, smooth, well demarcated, homogeneous hypoechoic solid lesion in 2nd and 3rd layer. Because there was no evidence of muscle proper layer invasion, ESD was performed for treatment (Fig. 3). Histopathologically, the tumor mainly located in the submucosa, and extended to mucosa. It formed solid nests of cells with abundant eosinophilic granular cytoplasm. Immunochemical stain of resected specimen showed that the cells were positive for S-100 protein (Fig. 4). These findings are typical of GCT. The patient made an uneventful post-ESD recovery and he was discharged on 2nd day after ESD.

\section{DISCUSSION}

GCTs were defined by Abrikossoff for the first time in 1926. GCT was described as a granular cell myoblastoma, since it was reported as a tumor arising from muscle in the tongue. ${ }^{16}$ Recently, GCTs were thought to be derived from neural origin. ${ }^{5}$

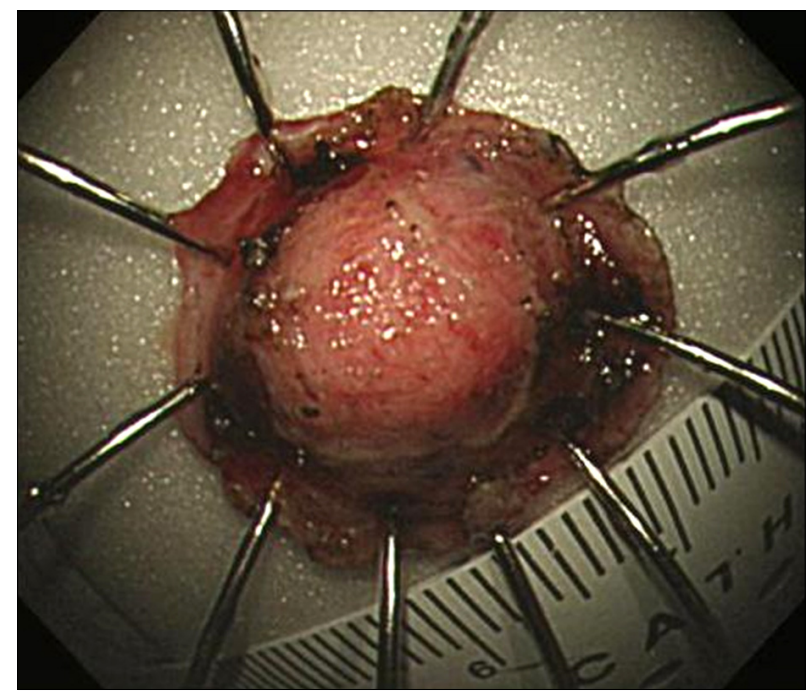

Fig. 3. The resected specimen showed yellow-whitish inner surface. 

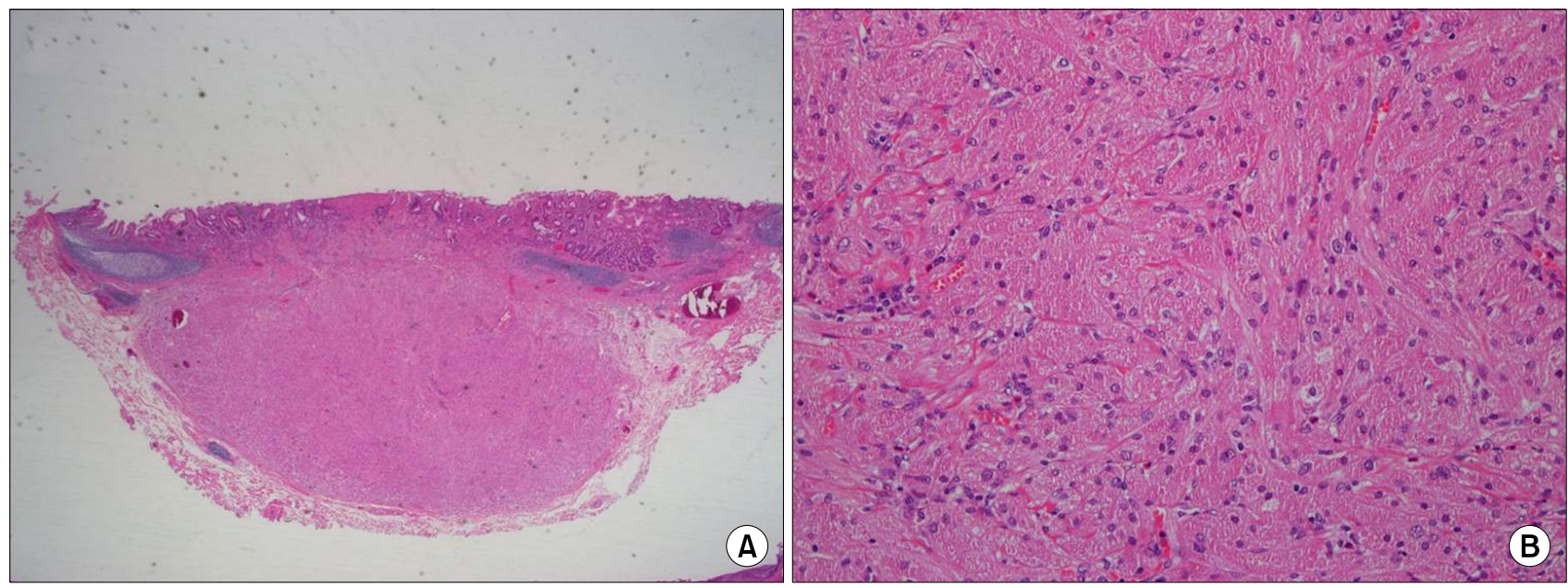

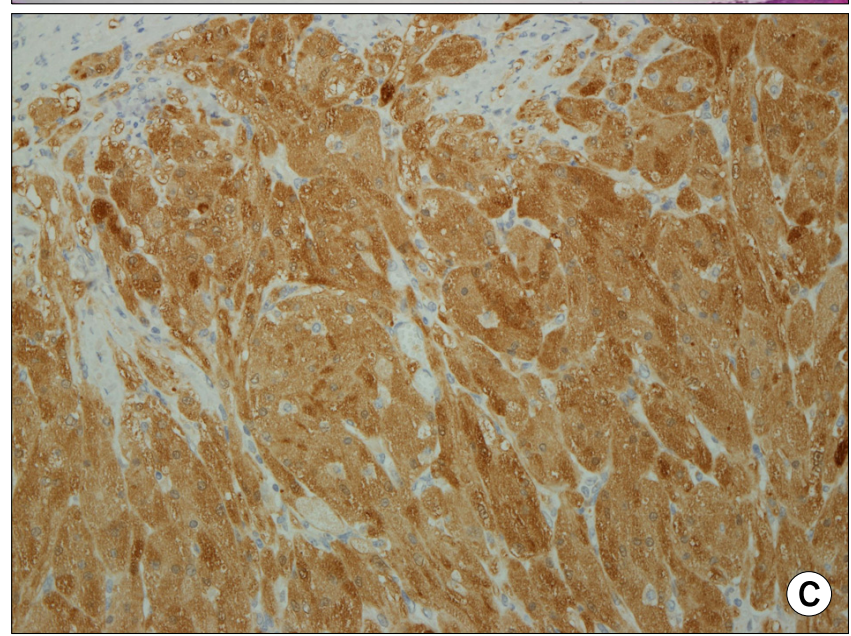

GCTs are uncommon, usually benign neoplasm that can be located at any sites, although they are usually in the skin or soft tissues. They are usually found in the oral cavity (40\%), skin and subcutaneous tissue (30\%), breast $(15 \%)$, or respiratory tract $(15 \%))^{2}$ The reported incidence of multifocal GCT ranges between 5 and $16 \%{ }^{16}$ The incidence of GCT in the GI tract is approximately $8 \%$, and most of GI GCTs are in the esophagus and large bowel. ${ }^{1}$ The GCTs of stomach are rare among GI GCTs. Only 24 patients with gastric GCT had been reported until 1995, and five more cases had been reported until 2006. ${ }^{6,8}$ Since 2006, eleven more cases have been reported (Table 1). ${ }^{9-15}$

GCTs of GI tract are usually benign, although a case of malignant gastric GCT was reported in 1996. ${ }^{4}$ Most malignant GCTs are larger than $4 \mathrm{~cm}$, and six histologic criteria were assessed: necrosis, spindling, vesicular nuclei with large nucleoli, increased mitotic activity $\left(>2 \mathrm{mi}^{-}\right.$
Fig. 4. (A) A large, polygonal tumor cells mainly located in the submucosa, and extended to mucosa. $(\mathrm{H} \& \mathrm{E}, \times 12)$. (B) The tumor cells were well-demarcated, and had abundant eosinophilic granular cytoplasm with small round nuclei (H\&E, $\times 200)$. (C) The tumor cells were positive for S-100 protein (S-100 stain, $\times 200)$.

toses/10 high power fields), high nuclear to cytoplasmic ratio, and pleomorphism. ${ }^{17}$

GCTs consist of large polygonal and fusiform cells disposed in compact nests, and GCTs have abundant eosinophilic granular cytoplasm with small round nuclei. ${ }^{6}$ GCTs are almost positive for S-100 protein and NSE, therefore GCTs are believed to be derived from Schwann cells. ${ }^{5,18}$

On the endoscopy, gastric GCTs can be mistaken for gastric carcinoid tumors. However, most gastric carcinoid tumors are usually multiple lesions and often appear small polypoid lesion with central depression or central ulcer. ${ }^{19}$ On the other hand, most gastric GCTs are a solitary lesion, and appear a yellowish-white lesion without central depression or central ulcer in our review. ${ }^{9-15}$ These endoscopic features can be helpful to distinguish gastric GCTs from gastric carcinoid tumors.

On the EUS, gastric GCTs usually appear as hypo- 
Table 1. Characteristics of Reported Eleven Gastric Granular Cell Tumor since 2006

\begin{tabular}{|c|c|c|c|c|c|c|}
\hline Case & Sex & Age (yr) & Size $(\mathrm{mm})$ & Treatment & EUS findings & $\begin{array}{l}\text { Esophageal } \\
\text { granular cell } \\
\text { tumor }\end{array}$ \\
\hline Rekha and Srinivas $^{9}$ & Male & 30 & 20 & Endoscopic resection & No mention & No \\
\hline John et al. ${ }^{10}$ & Female & 30 & No mention & Operation & No mention & Yes \\
\hline Park et al. ${ }^{11}$ & Female & 29 & $13 \times 10$ & Endoscopic resection & $\begin{array}{l}\text { 2nd, 3rd layer, homogenous, } \\
\text { hypoechoic, ill defined }\end{array}$ & No \\
\hline Monahan et al. ${ }^{12}$ & Male & 49 & 8 & Endoscopic resection & $\begin{array}{l}\text { 3rd layer, homogenous, } \\
\text { hypoechoic, well defined }\end{array}$ & No \\
\hline Pertile et al. ${ }^{13}$ & Male & 45 & $20 \times 13$ & Operation & No mention & No \\
\hline Min et al. ${ }^{14}$ & Male & 49 & 10 & Endoscopic resection & No mention & No \\
\hline Kahng et al. ${ }^{15}$ & Female & 33 & 17 & Endoscopic resection & $\begin{array}{l}\text { 2nd, 3rd layer, Homogenous, } \\
\text { hypoechoic, well defined }\end{array}$ & No \\
\hline Kahng et al. ${ }^{15}$ & Female & 76 & 10 & Endoscopic resection & No mention & No \\
\hline Kahng et al. ${ }^{15}$ & Female & 52 & 12 & Endoscopic resection & $\begin{array}{l}\text { 2nd, 3rd layer, Heterogenous, } \\
\text { hypoechoic, well defined }\end{array}$ & No \\
\hline Kahng et al. ${ }^{15}$ & Female & 46 & 13 & Endoscopic resection & $\begin{array}{l}\text { 3rd layer, homogenous, } \\
\text { hypoechoic, ill defined }\end{array}$ & No \\
\hline Kahng et al. ${ }^{15}$ & Male & 57 & 7 & Endoscopic resection & $\begin{array}{l}\text { 2nd, 3rd layer, homogenous, } \\
\text { hypoechoic, well defined }\end{array}$ & No \\
\hline
\end{tabular}

Table 2. Comparison of Endoscopic and EUS Findings between Gastric Granular Cell Tumors and Carcinoid Tumors

\begin{tabular}{lcc}
\hline & Granular cell tumor & Carcinoid tumor \\
\hline Endoscopic findings & Solitary & Multiple \\
Number & Yellowish-white in color, normal-appearing mucosa & Erythematous depression or central ulceration \\
Surface & Relatively inhomogenous than carcinoid & \\
EUS findings & Hypoechoic, but more echogenic than carcinoid & Hypoechoic \\
Homogeneity & Echogenicity &
\end{tabular}

echoic, homogenous lesions with smooth margins arising from the mucosa and/or submucosa. ${ }^{6}$ These EUS findings of gastric GCTs are similar to those of gastric carcinoid tumors, therefore differential diagnosis between GCTs and carcinoid tumors is very difficult. ${ }^{7}$ For this reason, we reviewed EUS findings of recent gastric GCTs since 2006. EUS were performed in the 6 cases among the recent 11 cases. ${ }^{11,12,15}$ When we observed closely the previous cases, EUS findings of recent gastric GCTs were slightly different from those of gastric carcinoid tumors. The EUS findings of gastric GCTS were relatively inhomogenous and more echogenic, compared with gastric carcinoid tumors. These EUS findings can be helpful to distinguish the gastric GCTs from the gastric carcinoid tumors as well as the endoscopic features (Table 2). Furthermore, EUS can be used to determine the invasion depth of gastric GCTs. If EUS can determine that gastric GCTs are limited to the submucosal layers, endoscopic resection has proven to be a safe and effective treatment for GCTs in the GI tract. ${ }^{15}$

Gastric GCTs are known to be strongly associated with synchronous esophageal GCT, although just one case was associated with synchronous esophageal GCT among recent 11 cases $^{3,8}$ and our case was not associated with synchronous esophageal GCT. Therefore, if gastric GCT is diagnosed, a careful endoscopic inspection will be required for evaluation of synchronous esophageal GCTs.

Most of gastric subepithelial lesions such as leiomyoma are difficult diagnosed by endoscopic forcep biopsy. However, GCTs usually locate in the deep mucosa or submucosa, which makes GCT possible to be diagnosed by endoscopic forcep biopsy, up to $83 \%$ of patients. ${ }^{20}$ In our case, endoscopic forcep biopsy could diagnose the lesion as GCT.

We report a case of a 31 year old man with GCT of 
gastric cardia, successfully diagnosed by endoscopic forcep biopsy and treated by endoscopic submucosal dissection, and we review the endoscopic and EUS findings of recent gastric GCT cases.

\section{REFERENCES}

1. Morrison JG, Gray GF Jr, Dao AH, Adkins RB Jr. Granular cell tumors. Am Surg 1987;53:156-160.

2. Lack EE, Worsham GF, Callihan MD, et al. Granular cell tumor: a clinicopathologic study of 110 patients. J Surg Oncol 1980;13: 301-316.

3. Wang LM, Chetty R. Selected unusual tumors of the stomach: a review. Int J Surg Pathol 2012;20:5-14.

4. Matsumoto H, Kojima Y, Inoue T, et al. A malignant granular cell tumor of the stomach: report of a case. Surg Today 1996;26: 119-122.

5. Seo IS, Azzarelli B, Warner TF, Goheen MP, Senteney GE. Multiple visceral and cutaneous granular cell tumors. Ultrastructural and immunocytochemical evidence of Schwann cell origin. Cancer 1984;53:2104-2110.

6. Radaelli F, Minoli G. Granular cell tumors of the gastrointestinal tract: Questions and Answers. Gastroenterol Hepatol (N Y) 2009;5:798-800.

7. Nakanome T, Yokoyama K, Takeuchi H, et al. Rectal granular-cell tumor difficult to distinguish from carcinoid tumor. Dig Endosc 2010;22:325-328.

8. Patti R, Almasio PL, Di Vita G. Granular cell tumor of stomach: a case report and review of literature. World J Gastroenterol 2006;12:3442-3445.

9. Rekha K, Srinivas CN. Granular cell tumor of gastric mucosa. Indian J Pathol Microbiol 2010;53:578-579.
10. John BK, Dang NC, Hussain SA, et al. Multifocal granular cell tumor presenting as an esophageal stricture. J Gastrointest Cancer 2008;39:107-113.

11. Park JS, Kim GH, Kim MR, et al. A granular cell tumor located in the gastric cardia. Korean J Gastrointest Endosc 2008;36:22-26.

12. Monahan KJ, Pelling M, Goldin R, Hoare J. Endoscopic removal of a granular cell tumor from the stomach using the Duette Multiband Mucosectomy Kit. Dig Dis Sci 2010;55:2688-2690.

13. Pertile D, Scabini S, Romairone E, Scordamaglia R, Rimini E, Ferrando V. Gastric Abrikosoff tumor (granular cell tumor): case report. G Chir 2010;31:433-434.

14. Min KW, Lee KG, Han H, Jang SM, Paik SS. Gastric granular cell tumour clinically mimicking carcinoid tumour treated by endoscopic submucosal dissection. ANZ J Surg 2014;84:985-986.

15. Kahng DH, Kim GH, Park DY, et al. Endoscopic resection of granular cell tumors in the gastrointestinal tract: a single center experience. Surg Endosc 2013;27:3228-3236.

16. Rose B, Tamvakopoulos GS, Yeung E, et al. Granular cell tumours: a rare entity in the musculoskeletal system. Sarcoma 2009;2009:765927.

17. Fanburg-Smith JC, Meis-Kindblom JM, Fante R, Kindblom LG. Malignant granular cell tumor of soft tissue: diagnostic criteria and clinicopathologic correlation. Am J Surg Pathol 1998;22: 779-794.

18. Stefansson K, Wollmann RL. S-100 protein in granular cell tumors (granular cell myoblastomas). Cancer 1982;49:1834-1838.

19. Basuroy R, Srirajaskanthan R, Prachalias A, Quaglia A, Ramage JK. Review article: the investigation and management of gastric neuroendocrine tumours. Aliment Pharmacol Ther 2014;39: 1071-1084.

20. Zhong N, Katzka DA, Smyrk TC, Wang KK, Topazian M. Endoscopic diagnosis and resection of esophageal granular cell tumors. Dis Esophagus 2011;24:538-543. 